Nordisk Tidsskrift for Kriminalvidenskab 2001

\title{
ER VOLDENS MØRKETAL FALDENDE?
}

Af speciallæge, Ph.D. Ole Brink \& vicepolitimester, Cand. Jur. Villy SøRENSEN

The dark figure of violence refers to the number of violent victimizations that go unreported to the police. Identifying the true extent of violent victimization requires measures above and beyond that available in police reports. The current study uses data collected from the casualty wards of the Institute of Forensic Medicine, Aarhus, to gauge the total extent of violent victimization. These data are then compared to victim reports collected by the Aarhus police. Changes in the ratio of total violence to reported violence allow the researchers to accomplish their primary goal, the identification of changes in the willingness to report violent victimization to the police over time.

This research is based on a dynamic cohort study initiated in Aarhus in 1981. Four waves of data were collected in 1981-1982, 1987-1988, 1993-1994, and 1999-2000. Casualty ward data suggest that the overall incidence of violence decreased significantly between the first study wave in 1981 and the most recent wave in 2000. During the latest period (1999-2000), the total number of casualty victims was 1,496. Comparison of casualty ward to police data suggest that victims have become significantly more likely to report violent victimization since the study began. In 1981-1982, 25\% of qualifying violent incidents were reported to the police. This proportion increased to 34\% in 1987-1988, 41\% in 1993-1994 and 58\% in 1999-2000. Willingness to report violence to the police is influenced by sex, age, victim-offender relationship, and where the violence takes place. The study concludes that estimates of the extent of violent victimization based solely upon police statistics may be misleading, since these statistics are biased by differences over time and between persons in willingness to report violence. It is recommended that police and health professionals cooperate in establishing better statistics and research.*

Voldens mørketal vedrører de voldsforbrydelser, der ikke er kommet til politiets kendskab. Fredriksson formulerede i 1962 mørketallet som det tal, hvormed antallet af registrerede voldsforbrydelser skal multipliceres for at få det faktiske antal, og samme definition bruger Wolf i $1973(1 ; 2)$. Hvis politiet havde kendskab til alle voldsforbrydelser ville mørketallet således være 1 , og hvis $1 / 3$ af volden anmeldes, så er mørketallet 3. I dagligdagen opfattes mørketallet dog oftest som differencen mellem det faktiske antal og antallet af anmeldelser (3).

* Title in English: Is the Dark Figure of Violence Decreasing? Original in Danish. 
Nielsen og Snare omtaler to slags mørketal: Det ene bestående af de voldsforbrydelser som politiet kender, men ikke registrerer (4). Det andet omfattende de forbrydelser, som forbliver skjulte for andre end ofret og eventuelt de nærmeste omgivelser. Ukendskab til mørketallet er hyppig årsag til fejlfortolkninger af kriminalstatistikken.

Op gennem 1980'erne og frem til midten af 1990'erne steg antallet af anmeldte voldsforbrydelser kraftigt. Denne udvikling har givet anledning til megen debat og danskerne har været meget bekymret for volden. Bekymringen og debatten har ofte været ansporet af anmeldelsesstatistikken. Hver gang antallet af anmeldelser steg, så blussede debatten op med fornyet styrke. Der er dog meget, som tyder på, at store dele af voldsdebatten i 1990'erne er foregået på et helt forkert grundlag. Jokeren er mørketallet og især ukendskabet til denne størrelse. I 1991 påpegede Kuchinsky, at de stigninger, man så i anmeldelsestallet, var betinget af en øget anmeldelses- og registreringstilbøjelighed, og samme vurdering har Balvig haft op gennem 1990'erne (5-7). I perioden fra 1981 og frem til 1994 er der i Århus gennemført tre et-årige voldsstudier, hvor man har suppleret politiets anmeldelsesstatistik med data fra skadestuerne (8). Herved har man været stand til at belyse vold, som politiet ikke havde kendskab til, og dermed kunne en del af mørketallet $i$ anmeldelsesstatistikken afdækkes. I 1999-2000 er der i Århus gennemført en opfølgning af de tre tidligere voldsstudier. Formålet med denne del af undersøgelsen har været at belyse, om de faktorer, som influerer på om volden politianmeldes, har ændret sig gennem tiden.

\section{Materiale og metoder}

Undersøgelsen er gennemført som et dynamisk kohortestudie, hvor kohorten er alle indbyggere i Århus politikreds. I 1999-2000 var der 322.000 indbyggere i politikredsen, og heraf var 31.000 af udenlandsk herkomst. Data er indsamlet i perioden 1. april 1999 og frem til 31. marts 2000. I studieperioden er alle voldsramte, som har været i kontakt med en af byens to skadestuer, Retsmedicinsk Institut (RI) eller politiet, registreret. Voldsramte er defineret som personer, der har været udsat for forsætlig legemsbeskadigelse eller død forårsaget af andre. Data fra tre tidligere et-års registreringer i henholdsvis 1981-1982, 1987-1988 og 1993-1994 indgår i det samlede materiale (8). Studiedesign, registreringspraksis og definition af voldsramte har været den samme i alle perioder. I de tre første studier blev data fra politiet indsamlet efter gennemlæsning af samtlige døgnrapporter fra ordens- og kriminalpoltiet. Sammenfaldene registreringer med sygehusene blev identificeret ved at sammenligne navn, personnummer, bopæl eller tid og sted for voldshandlingen. Siden undersøgelsen i 1993-1994 har Århus politi indført elektronisk registrering af alle anmeldelser i POL-SAS systemet. Det har betydet, at alle forurettede og sigtede personer nu kan identificeres alene ved personnumre, og alle andre 
relevante oplysninger vedrørende den enkelte anmeldelse kan hentes frem ved en enkelt dataforespørgsel. Fra POL-SAS er alle anmeldelser med henvisning til § 244 (simpel vold), § 245 (alvorlig vold), § 246 (særlig alvorlig vold), $\S \S 119-120$ (vold mod tjenestemand), $\S 216-217$ (voldtægt), $\$ 237$ (drab og forsøg på drab) og §288 (røveri) gennemgået. Undersøgelsen er godkendt af den Regionale Videnskabsetiske Komité og Registertilsynet, og tilladelse til gennemgang af politiets dataregistreringer er givet af Justitsministeriet.

\section{Resultater}

I 1999-2000 faldt det samlede omfang af vold i Århus signifikant i forhold til tidligere, men samtidig var der en signifikant større tilbøjelighed til at politianmelde volden. Samlet blev der registreret 1496 voldsramte i løbet af den et-årige undersøgelsesperiode, og heraf havde politiet kendskab til de $870(58 \%)$. Til sammenligning var andelen, som politiet kendte, $25 \%$ i $1981-1982,34 \%$ i 1987-1988 og 41\% i 1993-1994, se figur 1. Omvendt havde skadestuerne og Restmedicinsk Institut kendskab til 1106 (74\%) af de registrerede voldsramte.

Figur 1. Alle registrerede voldsramte $i$ de fire studieperioder.

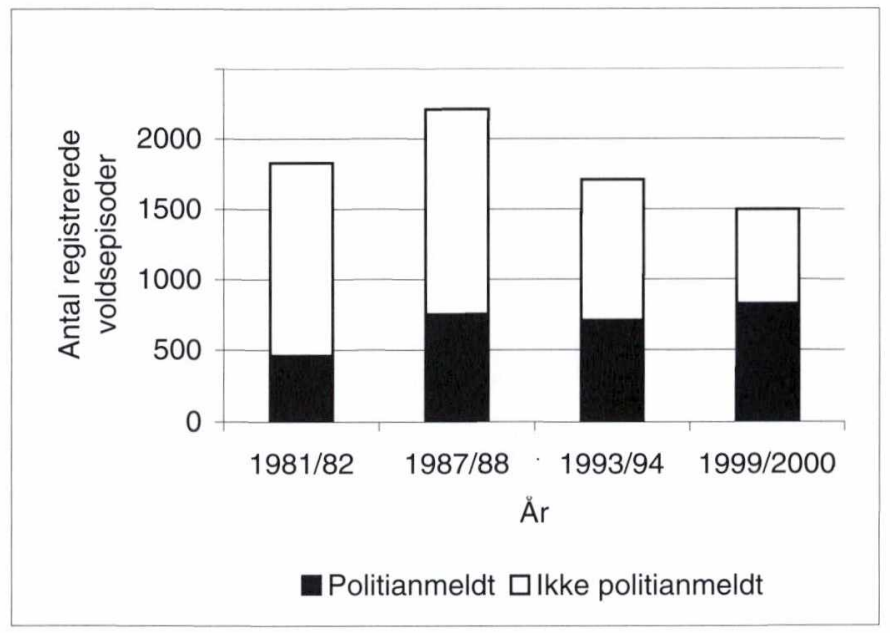


Alvorligheden af de læsioner, som de voldsramte blev behandlet for på skadestuerne, var uændret i forhold til tidligere. Som tidligere var der tydelig stigende tilbøjelighed til at politianmelde volden, jo mere alvorlig de fysiske skader var. Ved skadestuerne blev 55 personer behandlet for så alvorlige læsioner, at de nødvendigvis måtte være følger efter grov vold, men politiet havde ingen kendskab til disse voldsramte. I 1993-1994 var det tilsvarende 114 voldsramte (8\% af skadestueundersøgte) med fysiske skader efter grov vold, som politiet ikke kendte til. Såvel på skadestuen som hos politiet er det aldersgrupperne 15-19 år og 20-24 år, som dominerer i statistikken.

Tabel 1 viser, hvordan voldsanmeldelserne blev registret hos politiet i forbindelse med den første henvendelse. De anførte henvisninger til straffeloven er ikke nødvendigvis de samme, hvorunder sagen seneres afsluttes.

Tabel 1. Politiets klassifikation af de anmeldte voldsepisoder og relationen til samtidig undersøgelse på skadestue eller Retsmedicinsk Institut.

\begin{tabular}{|l|l|l|}
\hline $\begin{array}{l}\text { Ved politianmeldelsen } \\
\text { registreret som }\end{array}$ & Alle anmeldelser & $\begin{array}{l}\text { Undersøgt på skade- } \\
\text { stue/RI }\end{array}$ \\
\hline$\S 244$ (Simpel vold) & $589(100 \%)$ & $344(58 \%)$ \\
\hline$\S 245,1$ (kvalificeret vold) & $60(100 \%)$ & $48(80 \%)$ \\
\hline$\S 245,2$ (vold med skade) & $22(100 \%)$ & $16(73 \%)$ \\
\hline Voldtægt & $28(100 \%)$ & $10(36 \%)$ \\
\hline Vold mod tjenestemand & $79(100 \%)$ & $12(15 \%)$ \\
\hline Røveri & $75(100 \%)$ & $44(59 \%)$ \\
\hline Drab/drabsforsøg & $17(100 \%)$ & $7(41 \%)$ \\
\hline
\end{tabular}


Figur 2. Alderspecifikke incidensrater for alle registrerede voldsramte i relation til politianmeldelse.

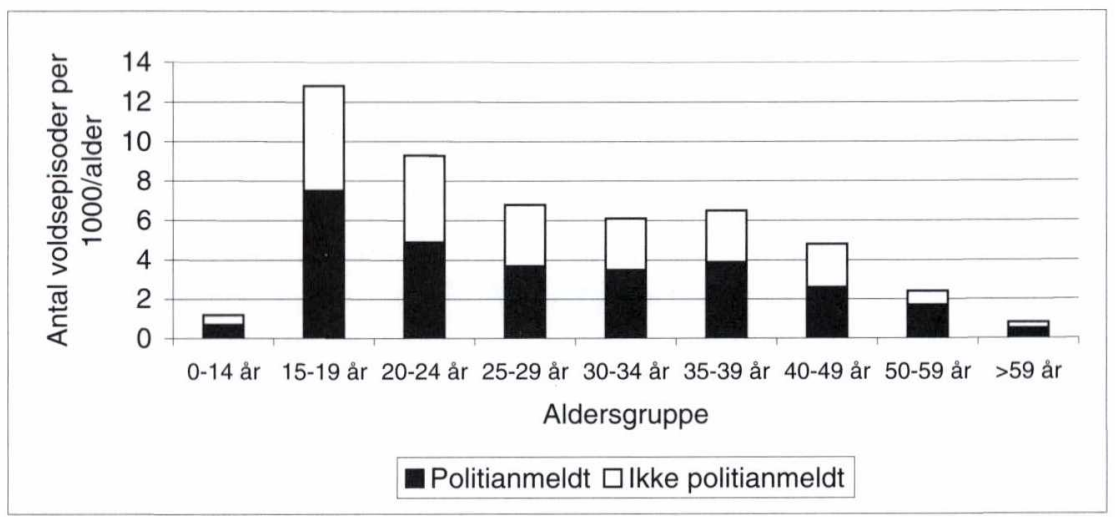

Figur 2 viser de aldersspecifikke incidensrater, hvor der tages hensyn til variationer i befolkningens alderssammensætning.

Relationen til modparten har betydning for anmeldelse. Kvinder udsat for vold fra ægtefælle/samlever anmeldte i $40 \%$ af de registrerede tilfælde volden til politiet. Til sammenligning var det i 1993-1994 34\% af kvinderne som anmeldte. Når volden blev udøvet af en tidligere ægtefælle/samlever, så anmeldte $47 \%$ af kvinderne i 1999-2000 episoden til politiet. Af samtlige voldstilfælde med en ukendt modpart, som blev registreret i dette studie, havde politiet kendskab til 59\% af tilfældene. Når modparten var en bekendt, så kendte politiet til $37 \%$ af de registrerede episoder.

Gerningsstedets betydning for anmeldelse fremgår af tabel 2. Personer som oplevede vold på arbejdet anmeldte i $81 \%$ af tilfældene volden til politiet, mens de i mindre grad (46\%) søgte akut lægehjælp på skadestuen. Voldsramte med dansk herkomst var i $58 \%$ af tilfældene i kontakt med politiet, mens tilsvarende $67 \%$ med herkomst fra mellemøsten, $48 \%$ fra fjernøsten og $44 \%$ med herkomst fra Afrika anmeldte volden til politiet. 
Tabel 2: Gerningsstedet for voldsepisoderne i relation til kontakt med politi og/eller skadestue.

\begin{tabular}{|c|c|c|c|}
\hline Gerningsstedet & $\begin{array}{l}\text { Voldsepisoder } \\
\text { registreret hos } \\
\text { politiet } \% \text { af alle) }\end{array}$ & $\begin{array}{l}\text { Voldsepisoder } \\
\text { registreret ved } \\
\text { skadestue } \\
(\% \text { af alle })\end{array}$ & $\begin{array}{l}\text { Alle voldsepisoder } \\
\text { med samme } \\
\text { gerningssted * }\end{array}$ \\
\hline Egen bolig & $\begin{array}{l}107 \\
50,5 \%\end{array}$ & $\begin{array}{l}181 \\
85,4 \%\end{array}$ & $\begin{array}{l}212 \\
100 \%\end{array}$ \\
\hline Anden privat & $\begin{array}{l}122 \\
69,7 \%\end{array}$ & $\begin{array}{l}99 \\
56,6 \%\end{array}$ & $\begin{array}{l}175 \\
100 \%\end{array}$ \\
\hline Arbejde & $\begin{array}{l}127 \\
80,9 \%\end{array}$ & $\begin{array}{l}72 \\
45,9 \%\end{array}$ & $\begin{array}{l}157 \\
100 \%\end{array}$ \\
\hline Skole & $\begin{array}{l}15 \\
45,5 \%\end{array}$ & $\begin{array}{l}25 \\
75,8 \%\end{array}$ & $\begin{array}{l}33 \\
100 \%\end{array}$ \\
\hline Værtshus & $\begin{array}{l}35 \\
48,6 \%\end{array}$ & $\begin{array}{l}60 \\
83,3 \%\end{array}$ & $\begin{array}{l}72 \\
100 \%\end{array}$ \\
\hline Diskotek & $\begin{array}{l}43 \\
56,6 \%\end{array}$ & $\begin{array}{l}57 \\
75,0 \%\end{array}$ & $\begin{array}{l}76 \\
100 \%\end{array}$ \\
\hline Café & $\begin{array}{l}16 \\
64,0 \%\end{array}$ & $\begin{array}{l}25 \\
100 \%\end{array}$ & $\begin{array}{l}25 \\
100 \%\end{array}$ \\
\hline $\begin{array}{l}\text { Gaden tæt ved } \\
\text { udskænkningssted }\end{array}$ & $\begin{array}{l}59 \\
54,1 \%\end{array}$ & $\begin{array}{l}97 \\
89,0 \%\end{array}$ & $\begin{array}{l}109 \\
100 \%\end{array}$ \\
\hline Gaden & $\begin{array}{l}271 \\
62,7 \%\end{array}$ & $\begin{array}{l}317 \\
73,4 \%\end{array}$ & $\begin{array}{l}432 \\
100 \%\end{array}$ \\
\hline Park, skov & $\begin{array}{l}11 \\
61,1 \%\end{array}$ & $\begin{array}{l}7 \\
38,8 \%\end{array}$ & $\begin{array}{l}18 \\
100 \%\end{array}$ \\
\hline Off. transport & $\begin{array}{l}6 \\
40,0 \%\end{array}$ & $\begin{array}{l}6 \\
40,0 \%\end{array}$ & $\begin{array}{l}15 \\
100 \%\end{array}$ \\
\hline Andet & $\begin{array}{l}19 \\
55,9 \%\end{array}$ & $\begin{array}{l}19 \\
55,9 \%\end{array}$ & $\begin{array}{l}34 \\
100 \%\end{array}$ \\
\hline Uoplyst & $\begin{array}{l}39 \\
28,3 \%\end{array}$ & $\begin{array}{l}108 \\
78,2 \%\end{array}$ & $\begin{array}{l}138 \\
100 \%\end{array}$ \\
\hline
\end{tabular}

*Korrigeret for voldsramte, som er registreret ved såvel politi som skadestue. 


\section{Diskussion}

Resultaterne fra denne undersøgelse tyder på, at mørketallet er faldet markant gennem de seneste år. Ved at kombinere oplysninger fra sygehusene med information fra politiet beskrives en udvikling i volden, som er i stærk diskrepans til den, der alene kan aflæses fra politiets anmeldelsesstatistikker. Diskrepansen kan forklares ved ændringer i mørketallene. I 1981-1982 var mørketallet 4 i forhold til alle de voldsramte, som vi registrerede, idet kun $25 \%$ politianmeldte. I 19992000 observerede vi, at $58 \%$ af de voldsramte politianmeldte, og dermed var mørketallet reduceret til 1,7 .

Det er desværre stærkt begrænset, hvad der foreligger af andre nordiske studier, hvor der er benyttet tilsvarende metodologi ved indsamlingen af data. Det blev forsøgt $\mathrm{i}$ forbindelse med et storstilet projekt omkring unge ofre for vold i Esbjerg, men blev opgivet på grund af metodeproblemer (9).

Rigspolitichefen gennemførte i 1995 en større offerundersøgelse, baseret på telefoninterviews, og her oplyste $1 / 3$ af dem som havde været voldsofre, at politiet havde kendskab til volden (10). Med henvisning til samme offerundersøgelse samt de tidligere Århus-studier, konkluderer Kyvsgaard i en rapport vedrørende vold i 1990 'erne, at anmeldelsestilbøjeligheden er steget gennem de seneste år (og dermed at mørketallet er faldet) (11).

Shepherd belyser indirekte ændringer i mørketallet i et studie fra Bristol, hvor man i perioden fra $1975 \mathrm{og}$ frem til 1990 noterede en nidobling i den politianmeldte vold, mens sygehusene "kun" observerede en seksdobling $i$ antallet voldsramte (12). I 1986 havde Bristol politi kendskab til $23 \%$ af de voldsramte, som kom til skadestuerne (13). The British Crime Survey fra 1996 beskriver faldende mørketal på baggrund af en generel øget anmeldelsestilbøjelighed (14). I et et-årigt studie fra Bergen i 1994-1995 oplyste 13\% af de voldsramte ved ankomsten til skadestuen (Legevakten), at volden allerede var anmeldt, og andre 31\% havde planlagt at gøre det (15). Island har op gennem 1990'erne oplevet samme paradoks som i Danmark, at den folkelige bekymring for vold har været stigende i en periode, hvor antallet af anmeldte voldsforbrydelser har været stabilt eller ligefrem faldende (16). Gunnilaugsson tilskriver massemedierne en del af ansvaret herfor.

Resultaterne fra Århus peger i tydelig retning af, at mørketallene kan være påvirket af, hvem som udøver volden, og hvor volden udøves. Betydningen af de enkelte faktorer kan variere over tid. Eksempelvis synes især mørketallet omkring volden på arbejdspladsen at have ændret sig i større grad end vold udøvet andre steder. Med Rigspolitichefens voldsofferundersøgelse i 1995 vurderede Balvig, at vold på arbejdet var betydeligt underestimeret (5). I 1999-2000 så vi en markant stigning i antallet af anmeldelser om vold på jobbet. Det er mest sandsynligt, at denne udvikling er betinget af en øget anmeldelsestilbøjelighed, og ikke at det er blevet farligere på jobbet. Mange i offentlige erhverv har nemlig fået indskærpet, at vold nu skal synliggøres gennem politiameldelse og indrapportering som arbejdsskade. Det er blandt andet praksis for ansatte ved Ârhus Politi i dag. 
Voldsstatistikken i Norge har i lighed med udviklingen i Danmark været præget af kraftige stigninger siden 1970 'erne. Olaussen er overbevist om, at stigningerne er betinget af en reduktion i mørketallet (17). Han angiver som en af årsagerne, at familienvolden sandsynligvis er blevet mere synlig i statistikken. Det er ikke længere så tabubelagt at politianmelde ægtefællen. Det er i tråd med resultaterne fra Århus, hvor $40 \%$ af de kvinder, som vi registrerede som ofre for hustruvold i 1999 2000, politianmeldte, mens det tilsvarende var 34\% i 1993-1994 og 21\% i 19871988 (18). Det er tidligere påvist, at kvindernes alder er signifikant relateret til tilbøjeligheden til politianmeldelse. Jo yngre jo større tilbøjelighed (18).

Årsager til ikke at politianmelde kan være mangeartede. I forbindelse med Århus-undersøgelsen i 1993-1994 blev der to år senere gennemført en opfølgende interviewundersøgelse. De, som ikke havde politianmeldt volden, blev spurgt om, hvorfor det var tilfældet. Fyrre procent mente ikke, at en anmeldelse ville gavne dem personligt, $17 \%$ var bange for gengældelse, $12 \%$ fandt episoden var for banal, og $11 \%$ mente, de selv havde en del af skylden (19). Efterfølgende havde flere fortrudt, at volden ikke blev politianmeldt. To år efter var dobbelt så mange som oprindeligt parate til at anmelde. Erfaringerne viser, at mange voldsforbrydelser kan betyde store konsekvenser for ofrene. Ofre udsættes uforskyldt for psykologiske, fysiske, sociale og måske økonomiske senfølger $(19 ; 20)$. Det skaber frustration og med tiden stiger ønsket om hævn gennem en politianmeldelse.

Resultaterne $i$ dette studie er baseret på oplysninger fra mere end 7000 voldsofre i en population på 300.000 indbyggere. Undersøgelsen præsenterer dermed det hidtil største datamateriale vedrørende ofre for vold, og det er samtidig det længste forløbsstudie.

Uanset metoden, hvormed der indsamles viden om vold, så vil volden altid have sine mørketal. Århus-studierne har naturligvis ikke belyst de sande mørketal, fordi vi har ingen kendskab har til alle dem, som ikke kom til skadestuerne. Det må man forholde sig til, når resultaterne bedømmes.

Generelt anses reliabiliteten og validiteten af data fra skadestuerne, RI og politiet for værende høj. Mørketallene i kriminalstatistikken er et produkt af selektionsbias hos politiet. Årsagerne til denne selektionbias hos politiet er indledningsvis nævnt med reference til Nielsen og Snare (4). Der sker også selektionsbias på skadestuerne, men den anses som værende meget lavere end hos politiet. Det er hyppigst omfanget af de fysiske skader, som er afgørende for, at voldsramte kommer til skadestuerne. Det vurderes, at betydningen af selektionbias på skadestuedata har været rimelig konstant gennem årene i og med, at der er benyttet samme metodologi i alle fire undersøgelsesperioder. Der er ikke noget, som tyder på, at tærsklen til at søge skadestue har ændret sig gennem årene. Såfremt den observerede udvikling med mindre vold i Århus skulle forklares ved væsentlige ændringer i selektionsbias, så skulle århusianerne være blevet mere "hårdhudede" gennem årene og dermed fravælge akut lægehjælp. Det er der absolut intet som tyder på - snarere tværtimod. 
Udviklingen i Århus afspejler ikke nødvendigvis udviklingen i resten af Danmark eller det øvrige Norden. Populationen, hvorfra data er indsamlet, repræsenter dog 6,4\% af den samlede danske befolkning, og befolkningens sammensætning afviger ikke væsentlig fra den gennemsnitlige danske befolkning, hvad angår køn og alder. Der boede i 1999 lidt flere med udenlandsk herkomst (10\%) i Århus i forhold til hele Danmark (8,2\%). Udviklingen i den politianmeldte vold i Århus gennem årene svarer meget godt til udviklingen i hele Danmark, se figur 3 . Der synes at være god grund til at antage, at den beskrevne udvikling i dette studie med mindre vold og samtidig reduktion i politiets mørketal, repræsenterer en generel udvikling i Danmark.

Figur 3. Alle anmeldte voldsforbrydelser $i$ Arhus og hele Danmark i perioden 1990 til 2000. Anmeldelserne inkluderer overtrcedelser af straffelovens paragraffer: $\$ \S 119-120,123,133,134 a, 237-241,244-246,249-262$ og 266-266a.

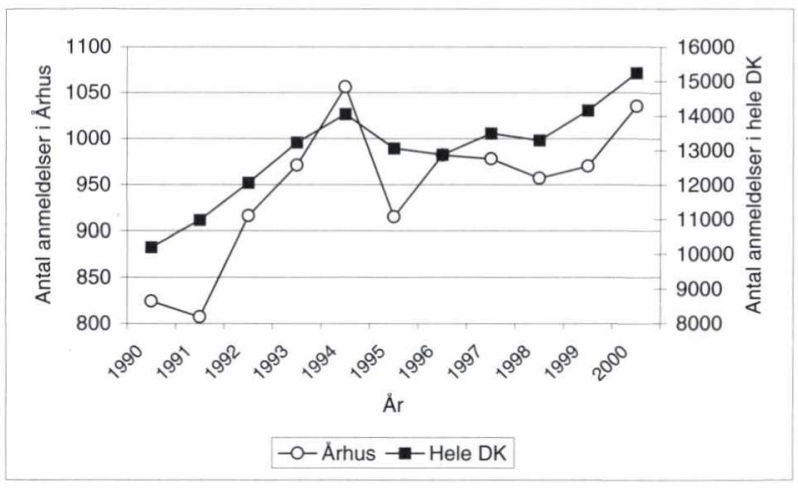

Kilde: Danmarks Statistik. (http://www.statistikbanken.dk)

Sammenfattende kan der konkluderes, at denne undersøgelse har bidraget med information omkring volden, som ikke var tilgængelig fra kriminalstatistikken alene. Resultaterne er opnået ved at samarbejde på tværs af faggrupper, og dette samarbejde kan anbefales, hvis vi fremover skal basere vores viden på et mere nuanceret grundlag. Ingen faggrupper har det fulde overblik, men sammen har vi et større. Derfor anbefales, at der etableres regionale og repræsentative centre, som i lighed med Århus-modellen tværfagligt indsamler og bearbejder data. Dette kan gøres for ganske få midler, og vil samtidig sikre et godt fundament for en målrettet forebyggelse af volden og efterfølgende evaluering af strategierne.

Taksigelser:

Justitsministeriets forskningspulje takkes for økonomisk støtte 


\section{LITTERATUR:}

1. Fredriksson G. Kriminalstatistken och kriminologien. Disputats. Stockholms Universitet, Juridiske Fakulteten, 1962.

2. Wolf P. Skader og tab forvoldt ved kriminelle handlinger. Redegørelse for et nordisk forskningsprojekt. Nordisk Tidsskrift for Kriminalvidenskab 1973; 61:85-110.

3. Henricson, I. Politiret. 2 ed. København: Jurist- og Økonomforbundets Forlag, 1999.

4. Nielsen BG, Snare A. Viktimologi. Om forbrydelsens ofre: teori og praksis. Aarhus: Aarhus Universitetsforlag, 1998.

5. Balvig F. Det voldsomme samfund. Om vold som problem og fængsel som løsning. København: Jurist og Økonomforbundets Forlag, 2000.

6. Balvig F. Bliver der flere og flere ofre for kriminalitet i Danmark? Kriminalistisk instituts Årbog 1992. København: Kriminalistisk Institut, 1992: 129-142.

7. Kutchinsky B. Voldsudviklingen i Danmark: En polemik. Kriminalistisk Instituts Årbog 1992. København: Kriminalistisk Institut, 1992: 117-128.

8. Brink O, Charles AV, Sabroe S, Jensen J, Sorensen V. Mindre vold og hyppigere politianmeldelse. Nordisk Tidsskrift for Kriminalvidenskab 1997; 84(2):103-114.

9. Unge ofre for vold. Opsamling og rapportering af tværsektorielt pilotprojekt i Esbjerg for unge voldsofre og deres pårørende. Esbjerg: Voldssekretariatet, Esbjerg Politi og Esbjerg Kommune, 2000.

10. Rigspolitichefen. Voldens omfang og karakter i Danmark. Oversigt over resultater fra voldsofferundersogelsen i 1995. København: Information fra Rigspolitichefen, 1997.

11. Kyvsgaard B. Vold i 1990 'erne: den registrerede og faktiske voldskriminalitet, de strafferetlige sanktioner for vold, komparative perspektiver på voldsniveauet og på straffe for vold i Danmark samt undersøgelser af befolkningens bekymring og frygt for vold og kriminalitet. København, Justitsministeriet. 2000.

12. Shepherd JP, Ali MA, Hughes AO, Levers BG. Trends in urban violence: a comparison of accident department and police records. J R Soc Med 1993; 86(2):87-88.

13. Shepherd J, Shapland M, Scully C. Recording by the police of violent offences; an Accident and Emergency Department perspective. Med Sci Law 1989; 29:251-257.

14. Mirrlees-Black C, Mayhew P, Percy A. Home office statistical bulletin. The 1996 British Crime Survey. England and Wales. 19/96, 1-80. 1996. London, A publication of the Government Statistical Service.

15. Steen K, Hunskår S. Vold i Bergen. Et ettårsmateriale fra Bergen Legevakt. Tidsskr Nor Lægeforen 1997; 117(2):226-229.

16. Gunnilaugsson H. Kriminalitet og straffepolitik i Island. Nordisk Tidsskrift for Kriminalvidenskab 2000; 87(1):38-47.

17. Olaussen L. Voldskriminalitetens utvikling de to siste tiårene. Nordisk Tidsskrift for Kriminalvidenskab 1995; 82:97-116.

18. Brink O. Vold i Århus. Ph.D.-afhandling. Aarhus Universitet, 1999.

19. Brink O. Voldens senfølger set fra offerets synsvinkel. Tidsskr Nor Lægeforen 2000; 120:705709.

20. Elklit A, Brink O. Akut traumatisering efter vold. Ugeskr Læger 2001; In press.

Adresse: Ole Brink

Ulykkes Analyse Centret

Århus Amtssygehus

Tage Hansens Gade 2

8000 Århus C

E-mail: o.brink@dadlnet.dk 